\title{
Socio-Philosophical Bases of Research of Modernization Processes in Uzbekistan
}

\author{
Shakhnoza Madaeva, Khojiev Tunis
}

\begin{abstract}
Large-scale reforms and complex modernization carried out in the country after independence are studied from the positions of various social sciences and humanities. However, the history of modernization processes in our country has not been paid sufficient attention to the problem of chronological cycles. This chapter examines the philosophical and historical foundations of the complex state of modernization in the republic, and they are divided into specific chronological stages. At the same time, the comprehensive development programs ("Uzbek Model" of Development, the Concept of Intensification of Democratic Reforms and Formation of Civil Society in the Country, Strategy of Action for the Further Development of the Republic of Uzbekistan) for the reform of the Republic of Uzbekistan are taken as a determinant. Accordingly, the peculiarities of the stages of modernization in the Republic of Uzbekistan will be determined and the transformation model of the republic will be opened.
\end{abstract}

Keywords: Uzbek Model, "Reformation and Bukhara", state ruled by law, Uzbekistan's latest history, modernization, democratization, law policy, Strategy of Actions along Five Priority Directions of the Development of the Republic of Uzbekistan in 2017-2021, national legislation, lawmaking.

\section{INTRODUCTION}

It is known that from the earliest days of our independence up to the present time, wide-ranging reforms have been undertaken in our country to develop all areas of public life. Consistent and effective implementation of these reforms requires the development of many well thought-out, well-grounded, scientifically based mechanisms. It is clear that there is a need for strong and fundamental research in the modernization of the country. This is because the country in which the modernization is taking place must develop theoretical developments that have deep scientific basis for choosing their own modernization or development path. There is a growing need for theoretical ideas and developments that combine the existing social, economic, political and cultural conditions in the country, the ethnic composition of the population and, accordingly, the national mentality, world experience, international situation and historical experience.

From the basic living of self-determination until the nearby day, here engage in been numerous studies faithful to the assay of the issues of rebuilding of our country, which obtain tried to envelop these issues to certain extent. These studies, along with defining features of modernization of the country, predicting prospects and studying international

Revised Manuscript Received on October 15, 2019.

Shakhnoza Madaeva, Professor of the National University of Uzbekistan named after Mirzo Ulugbek (DSc), Uzbekistan.(Email: sh.madaeva@nuu.uz)

Khojiev Tunis, Senior Lecturer $(\mathrm{PhD})$ of the National University of Uzbekistan named after Mirzo Ulugbek, Uzbekistan.(Email: X_tunis@nuu.uz). experience in this field, can also be found in the study of the history of Uzbekistan's modernization and the periodization of its development stages. Certainly, it is tough to recognize the history of the reconstruction development in Uzbekistan, plus separate, large-scale elemental studies designed at chronologically in-between this procedure into periods or stages. However, a great deal of the make inquiries on the country's reconstruction replica reveals references to this issue. Specific research has been undertaken in recent studies of Uzbekistan or any other area: government and governance, social protection, spiritual development, legal sphere, property formation, transition stages, economic reforms, and so on.

However, nearby is no controlled examine fervent to classifying the wide-scale reforms in the country from the argument of view of holistic renewal paradigms. Moreover, from the point of view of the paradigm of modernization, it is difficult to find work to classify the wide-ranging reforms in the country. Of course, each of these problems can serve as the subject of several separate studies.

\section{REVIEW OF THE LITERATURE ON THE TOPIC}

The issue of rounding up the processes of modernization of Uzbekistan has been studied to some extent during the years of independence. Such studies reveal the history of Uzbekistan's modernization processes, not in a holistic manner, but in separate areas. Furthermore, in the monographs, brochures and articles of Juraev N. [1], Jakbarov M. [2], A.Kadyrov [3], A.A. Azizkhodjaev [4] Nazarov K.N. [5] Boboev H. [6], Jumaev R. [7], Musaev F.A. [8], Otamurotov S.O. [9], Ergashev I. [10], Kyrgyzbaev M. [11], Abdullaeva M.N. [12], Amanov B. [13], this issue has been deeply analyzed.

\section{RESEARCH METHODOLOGY}

During the research, the following general and philosophical methods were used: historical, objectivity, abstraction, concrete, systematic analysis, comparative analysis.

\section{ANALYSIS AND RESULTS}

Most studies focused on the history of modernization processes in Uzbekistan tend to have a long history. Even in the determination of the starting point of the processes of modernization of the peoples of Central Asia, in particular, 
in Uzbekistan, one can see the work of the Middle Ages. For example, B.Omonov's monograph on Models of Political Modernization and the Experience of Uzbekistan offers the following points. "Today, politics and philosophers have found that the modernization of Uzbek society dates back to the Middle Ages. Professor Anvar Kadyrov, Doctor of Philosophy wrote: "The great ideas of renewing society and combining religious ideas with lifebuilding ideas were put forward by the great scholar Khoja Bakhouddin Naqshbandi," - The work ethic of Bakhouddin Naqshbandi can be compared to the Protestant work ethic of Christianity (M. Luther, A. Calvin).The Western civilization, which was in the foot of the Eastern Renaissance science, advanced ahead of the East in the development of Protestant labor ethics."[14] However, the emphasis on modernizing criteria, which is based on the generalization of generally accepted definitions of modernization, is clear that this approach is inadequate.

Modernization is rarely stable; it affects all spheres of society, social institutions, and it involves radical changes in all spheres of society. Using a systematic approach, we propose that modernization should be viewed as a multilevel process affecting all sectors of society [16].

The first level of modernization is related to the attitude of members of society towards modernization: industrialization, urbanization, mass production, commercialization are, in essence, universal in these processes.

At the second level of modernization, there is a change in the political system [17]. The main feature of the modernization of the political system is traditionally the introduction of the constitution, which is the development of mechanisms for the separation of powers, the rational interaction of society and authorities.

The third level is the conceptual level. In this level, the foundations of the political system and its functions are fully created. To this extent, the social and cultural features of the region are fully presented [18].

Modernization is a systematic renewal of the whole society, first of all the human mind. "Modernization has gone through social, economic and political dimensions and revolutionized the human mind. Moreover, it has uprooted human values and beliefs and transformed the emotional structure of life."[19] Peter Berger wrote in his book "Understanding Modernity" about the transformation of public consciousness in contemporary society. He identifies five important dilemmas that, according to the author, are fundamental and practical.

"The first dilemma is the result of appeal, which is one of the most important features of modernity, with the exception of small, unified groups in society, where there is a weakening of social relations, where people feel solidarity and find meaning in life. At the level of substratum envisioned by the author, emotionally charged and thoughtprovoking behaviors may be exacerbated in all areas of human life. The author sees the root of the appeal in social institutions based on society: this is reflected in the capitalization market and the bureaucratic state and the technologically advanced economy. Furthermore, it is also reflected in the domination of technology over the non- economic sector of society, its aggression in large cities, and, finally, the media.

The second dilemma is a dramatic change in temporal structures in human perception in the future, when the future becomes a criterion not only for imagination but also for activity. If we view the process of modernization as a transformation of human perceptions over time, this would be one of the most misleading definitions of modernization.

Temporal transformation occurs in three ways. In everyday life, it can be compared to a table, a wall clock, which becomes a common dominant. At the community level, the government and major organizations implement projects through various plans, such as five-year, sevenyear, multi-year plans or concepts such as "stages of economic growth" or "communism." At all three levels, the new temporality is strongly controversial in the perceptions of the people, which is especially true of last-century regimes.

The third dilemma is individualization. Modernization encompasses all the features of the individual that are separated from the collective and the social community. In this context, the emphasis is on the confrontation between society and the individual that has remained constant throughout history. Individualization is the opposite of this abstraction, and these two concepts are paradoxically interrelated. External socio-structural causes are also manifested by the weakening of the collective values that support the individual up to society. The paradox of these issues is that these communities functioned as abstract mega structures, while the individual felt extremely complex and unique to society, and it was hardly possible to play that role in abstract social institutions.

The fourth dilemma is liberation. The most important aspect of modernization is that many aspects of human life that are predetermined are now regarded as individual or community-driven processes. In this sense, modernization also means a lot of choices. One of the most attractive principles of modernity is the following: things are not the same as they were before. This is the dynamics of modernity, its aspiration for innovation and revolution. Traditions are no longer mandatory, the status quo may change, and the future will open new horizons.

The dilemma of secularization. Modernization can pose a serious threat to religious beliefs and practices. However, this does not mean that religious beliefs will disappear. However, it is also important to note that secularization has led to the weakening of popular beliefs in most societies [20].

Summarizing approaches to the definition of this concept, modernization can be said to be a complex process that includes political, economic, social, environmental, demographic, and psychological changes. Obviously, in the Middle-Ages, the criteria for modernization enumerated in the West and the East were virtually non-existent. Only the criteria for individualization and secularization of modernity show that there is no element of this process, not only in the West, which is widely recognized in the East as the primary 
source of modernization. Of course, the study by A. Kadyrov emphasizes that the idea of labor glorification of the Naqshbandi principles is closely linked to the Protestant ethics of the Westernization model of modernization, which is now recognized as the classical theory of modernization. But from a philosophical historical point of view, the similarity of one doctrine with another does not mean that these doctrines are accurate. After all, they grew up at different times, in different regions and in different sociocultural environment and in socio-economic, historical and political conditions. To be more precise, it is hard to believe that this approach is correct even on the principle of antiquarianism. Moreover, as mentioned above, the processes of formation and dissemination of the Naqshbandi principles are neither local nor chronologically compatible with theories and ideas of modernization. This is because the medieval Arab-Muslim countries, where the teaching was formed and spread widely, dominated the social relations inherent in traditional society. In this context, this doctrine should not be considered as a doctrine intended to modernize society. It can only be said that this was a result of the need to suppress the growing tendency of ascetics in the medieval Muslim East, where the teachings of mysticism were widespread.

This article, which covers the history of the processes of modernization in the Republic, focuses on objective analysis, based on the principle of unity of historicity and logic, based on the same criteria.

The study of the history of modernization processes in the country also focuses on the analysis of ideas and activities of the widespread enlightenment and the Jadids movement that emerged in the late 19th and early 20th centuries. However, often the ideas of enlightenment and intimidation are not analyzed in terms of the modernization paradigm, but the autobiographies of the movement's representatives, as well as their aspirations for the national liberation movement. In this context, there is a great need for exploring the reforming movements of enlightenment and agitation from the point of view of modernization.

Certainly, there is no doubt in the works of the representatives of the enlightenment and the Jadids movement that ideas aimed at radical reforming of society was put forward. In particular, in the book "Reformation and Bukhara", published by A. Fitrat in 1917, we can see many ideas aimed at reforming the Bukhara emirate. The essence of A.Fitrat's political program "Reformation and Bukhara" or modernization project can be summarized as follows:

Chapter I: The main issue in the land-water relations was to free the grain-growers from the kafsan "tax paid for mullahs", and to distribute the land of the government on which the water was removed to the landless population.

Chapter II: Foundation "Vaqf" land can play a major role in making Bukhara the most cultured city, provided that mosques, religious and secular schools, libraries, orphanages, hospitals, and kitchens for the poor are provided.

Chapter III: Bukhara residents under the age of 22 must be called up for military service, exempting sick and disabled.

Chapter IV: All financial work is needed. For this purpose, a Ministry of Finance should be established and the
Treasury Department should also be accountable to the Treasury.

Chapter V: Appointment of officers in Castle by the Ministry of Interior Ministers and judges should not intervene in court proceedings.

Chapter VI: Judiciary and law enforcement agencies should be separated. The Ministry of Justice and Judicial Ministries should be introduced in two phases: the lower and the upper.

Chapter VII: Police must maintain peace among the public. This is an important unit of defense in the state.

Chapter VIII: The future government should pay attention to road and mineral resources, rehabilitate roads, build roads and railways.

Chapter IX: The Ministry of Foreign Affairs shall be appointed for relations with Russia and other governments. This minister will also be the chairman of the cabinet of ministers.

Chapter X: The Chairman of the Cabinet of Ministers is appointed in accordance with the decree of the Emir.

Chapter XI: A school may be opened by any person other than the State and Foundation Schools.

Chapter XII: Marketplace in populated areas, streets and roads, etc. communal Soviet bodies should be established to represent value.

Chapter XIII: The supervisory authority consists of two stages: 1) ten special lawyers and ten people; a stage comprised of representatives; 2) Free Press [21].

The reform efforts of the Jadids movement have been dominated by the idea of human modernization, namely, the modernization of education, science and culture. At first, these ideas, which were at the level of theoretical views, later became a great reformist movement. In particular, the work of A.Fitrat "Reformation and Bukhara" can be considered as a strategic development project aimed at realizing the country's modernization, or as an original model of oriental modernization in the Islamic socio-cultural environment. However, due to certain social and political obstacles, the massive reform movement initiated by the Jadids to modernize Turkestan could not end.

Modernization processes in Uzbekistan continued to a certain extent during the post-Soviet colonial period. The modernization of the country in the post-Soviet period was manifested as part of the uneven modernization processes that took place in the Soviet Union.

It is not a secret that the Republic of Uzbekistan was one of the raw materials bases of the Soviet Union at that time. In particular, the economic system of the Republic was mainly focused on the cultivation of raw cotton. The colonies, roads, warehouses, production system and many other elements of infrastructure that were built in the country at that time, were largely made up of colonial facilities. Modern enclaves were formed, with quarters inhabited by representatives of the localized elite. Such societies are defined as dualistic societies [22].

Technological modernization in Uzbekistan took place during this period. But it is hard to say that modernization in 
this area has been done only to improve the economy of Uzbekistan. Most of the manufacturing enterprises (104 of the 308 enterprises to Uzbekistan) evacuated to the Central Asian Republics (Leningrad Textile Plant, Kyzyl-Aksoy, Rosselmash, Sumsk compressor and Dnepropetrovsk carborund plants, Moscow Electro-cable and Podiumniknik factories, National Railway Machine Plant, Chkalov Aviation Plant, Krasny Put, Kiev TransSignal, and Stalingrad Chemicals: of these, 55 enterprises were located in Tashkent and Tashkent region, 14 in factories and factories in Samarkand, 22 in the Fergana Valley, and two in Bukhara region [23].) These factories were brought not for the development of the national economy, but because Uzbekistan was a zone free from war. In addition, most of the major industrial enterprises that existed in the country during the Soviet era were directly subordinated to Moscow, and their revenues did not go directly to their local budgets. For example, most of the major factories and factories operating in natural resources were managed and funded from Moscow. Uzbekistan was still a rich mineral base for the metropolis. There are many unique deposits of gold, copper, lead, zinc, tungsten, uranium, natural gas and coal. On the basis of these deposits factories, oil and gas industry enterprises, new cities and settlements were built. In the $60 \mathrm{~s}$ and 70s of the last century large gold mining industry was created and developed in the country, gold-mining factories, gold-mining complexes and copper ore processing factories were put into operation. At the same time, the production of high-quality gold that meets international standards began. However, these resources were taken to the Center and Uzbekistan was of no use. Because, Uzbekistan which squeezed by the colonialist regime, was not the owner of any of its wealth, and could not enjoy its benefits independently. The majority of major industries and major enterprises in Uzbekistan (about 70\%), including nonferrous metallurgy, were directly subordinated to the Union Ministries; the republic was not the owner of its own production. Extraction and transportation of gold, uranium, non-ferrous metals and other minerals was carried out by the central authorities themselves without the consent and control of the governing bodies of Uzbekistan. Only a small part of the profits could be transferred to the national budget [24].

In addition, the cities and industrial facilities created in the country as industrial zones served mainly the colonial people. We can give these enclaves as an example such as Angren, Zarafshan, Uchkuduk, Bekabad, Almalyk, Marjanbulak.

During the Soviet era, Uzbekistan also underwent a process of modernization in science, education and culture. But it is known that the level of modernization in these areas was somewhat superficial and ineffective. In general, the modernization carried out in the republic during the postSoviet period served the interests of the colonial peoples, rather than the welfare of the people of Uzbekistan.

After gaining independence there was a great need for radical modernization of the country. This required, first of all, the development of a model of modernization that combined the economic, political, socio-cultural factors and the experience of the leading countries of the world. In general, the modernization process carried out over the years

of independence can be conditionally divided into 3 stages (Uzbek model of development, "Concept of further deepening of democratic reforms and formation of civil society in the country", "Strategy of action"), due to the adoption of three major development programs.

The first stage is the adoption of the "Uzbek Model" of Development, the establishment of the legal and organizational framework for state construction, the formation of private property, the development and implementation of a continuous education system, the implementation of land reform, the development of national legislation, the creation of banking and financial systems, the establishment of foreign policy and economic relations. During this period: 1) to free the economy from ideology; 2) ensuring the rule of law; 3 ) recognizing the managerial role of the state as the principal reformer; 4) conducting a strong social policy, taking into account the specifics of our country; 5) The "Uzbek Model" of development, which consists of the principles of gradual implementation of political and economic reforms, was of great strategic importance. The "Uzbek model" as the distinctive model can be further understood from the essence of the Concept of further deepening of democratic reforms and formation of civil society in the country (November 12, 2010), issued by the First President I.A Karimov. According to this, the Uzbek model of development enriched the national experience gained during independence and theoretical and practical aspects of building a prosperous society and legal state, tested in developed countries. This concept emerged as a promising program to provide legal framework for this process in defining the priorities and objectives of civil society and the rule of law.

The second stage of the comprehensive modernization process, implemented in Uzbekistan since independence, began with the adoption of the Concept of further deepening of democratic reforms and formation of civil society in the country. During this period, a number of organizational, institutional and legal reforms were implemented to modernize the country related to governance, legislation, information sector, economy liberalization, electoral system, improving the activities of NGOs. At this stage, "the Concept of further deepening of democratic reforms and formation of civil society in the country" served as a strategic development program.

The third stage of the modernization of Uzbekistan's independence is marked by the adoption of the 'Strategy of Action'. In summary, summarizing the analysis presented in the same article on the modernization of Uzbekistan's society can be cycled as follows:

The history of modernization in the Republic can be divided into three stages:

1) Stage of modernization, caused by the Jadids movement.

2) A period of constructive modernization projects aimed at adaptation to the occupation system.

3) The stage of modernization that took place during the years of independence. 
Certainly, during each of these three periods there were significant changes in specific social relations, organizational institutional structures, and economic and industrial development and a system of values.

The period of independence plays an important role in the history of modernization of Uzbekistan. The modernization of this period reflects the radical transformation of the people and the state. Of particular importance is the problem of rounding the complex modernization processes that have taken place during this comprehensive period. Of course, there may be different approaches to this. For example, a classification of the history of modernization of the independence years can be made on the modernization of a particular area, on the basis of specific historical events that occurred during the years of independence, or on the basis of laws envisaging significant changes.

The present study proposes that the problem of periodization of modernization of this period is solved by adopting strategic development programs aimed at reforming a region from the position of the universally recognized modernization paradigm. Especially in countries that use accelerated or chasing modernization models, most of the research is cyclical according to the same strategic development programs. Because, according to the Westernization model, modernization took place in Western Europe and the USA as a natural and historical process.

\section{CONCLUSIONS}

Thus, the modernization process over the years of independence can be divided into three consecutive terms in connection with the adoption of special strategic development programs adopted in the country.

The first is the first stage of the adoption based on the Uzbek Model of Development. This period is characterized by a number of features such as national state structures, legislation, national self-awareness, colonial complications, and emergence of new economic and financial structures.

The second stage, related to the adoption of the Concept of further deepening of democratic reforms and formation of civil society in the country. At this stage, a number of institutional and legal reforms were implemented to modernize the country, including the governance, legislative, information, economic liberalization, electoral system, and improvement of the activities of NGOs. In the first period the foundations of statehood were formed, and in the second period fundamental ideas related to the improvement of democratic civil society structures were put forward and implemented.

The third stage based on the adoption of the "Action Strategy". At this stage in the process of modernization taking place in the country, we entered a stage of reforms at the level of international standards, taking into account the real problems in the country. Especially during this period the impact of the innovation model on the model of modernization of the republic has increased. In addition, one of the important conditions for accelerated modernization has been the ability of the country to open its doors to its neighbors.

The findings of the study can be used to examine the features of the processes of modernization in Uzbekistan, as well as to give lectures on sociology, history of philosophy, philosophy, political science, economics, history and other disciplines.

\section{REFERENCES}

1. Juraev N. The concept of renewal: creation, evolution and practice. - Tashkent: Spirituality. 2002. P. 214

2. Zhakbarov M. Historical and philosophical foundations of the idea of a perfect human being. - Tashkent: Tafakkur. 2011. P. 256.

3. Kadyrov A. Traditional society and strategies for its modernization. - Tashkent: TSU. 2006.

4. Azizkhodjaev A.A. Statehood and spirituality. -T .: "Sharq", 1997;

5. Nazarov K.N. Axiology. The philosophy of values. Tashkent. 2004;

6. Boboev H. About national statehood. Tashkent. 1999;

7. Jumaev R. The state and society: on the way to democratization. - Tashkent. East 1998;

8. Musaev F.A. Philosophical and legal bases of building a democratic state. - Tashkent: Uzbekistan, 2007;

9. Otamurotov S.O., Spiritual and spiritual revival in Uzbekistan. - Tashkent: The New Generation, 2003

10. Ergashev I. The philosophy of development. Tashkent: Academy, 2000;

11. Kyrgyzbaev M. Civil society: political parties, ideologies, cultures. Tashkent. East, 1998;

12. Abdullaeva M.N. Philosophical and methodological analysis of the process of modernization. Tashkent: Institute of Philosophy and Law. 2010. - 169 p.

13. Omonov B. Models of political modernization and the experience of Uzbekistan. Monograph. Tashkent: Science and Technology. 2012. P-112.

14. Omonov B. Models of political modernization and the experience of Uzbekistan. Monograph. T: Science and Technology. 2012. P-112.

15. Kokarev K. On the evolution of political reform in China / K. Kokarev // Problems of the Far East. - 2004. - No. 5. P. 91.

16. Balchindorzhieva O.B. Methodological features of the study of modernization // Bulletin of the East Siberian University of Management and Technology. 2014, No. 1 (46). - P. 134.

17. Berger P. Facing upto Modernity - New York. - 1977 - P 127- 128.

18. Berger P. Facing upto Modernity - New York. - 1977 - P 128- 132.

19. Parsons T. System of modern societies. 1970. // Name of the resource: Digital Library on Philosophy. Access mode:http://filosof.historic.ru/books/item/f00/s01/z00010 64/st000.shtml

20. Berger P. Facing upto Modernity - New York. - 1977 - P. 128- 132

21. Madaeva Sh.O. Features of formation of democratic thinking in the Uzbek mentality 09.00.11 - Social Philosophy Thesis for the degree of Doctor of Philosophy. Tashkent. 2009. B-121.

22. Toyganbaeva Agina Erkinovna "Experience of modernization of the countries of Southeast Asia and its adaptation in the conditions of modern Kazakhstan" The dissertation for the degree of Doctor of Philosophy (PhD). P-42.

23. The Authors Team. The modern history of Uzbekistan. T $\therefore$ East NMK. 2000. B-440-441.

24. Authors' Team. The modern history of Uzbekistan. T . East NMK. 2000. B-525-526 